\title{
Antidiscrimination Law in the European Community
}

\author{
Erica Szyszczak
}

\begin{abstract}
This Article examines how an economic international Treaty arrangement in 1957, which was openly and unapologetically aimed at trade liberalization, arrived at including such fundamental social constitutional values in the Treaty of Lisbon 2007. This Treaty facilitates the constitutional framework for political and economic co-operation in the newly enlarged Union of twenty-seven Member States, setting the agenda for the next fifty years of European integration. In making this journey we will not be taking a nostalgic look backwards at the achievements of the Community, but we will examine how the groundwork was laid to lead what became the Union to recognize new forms of fundamental values capable of international recognition. This Article first examines the underlying sources for an antidiscrimination concept in Community law and then moves on to analyze how the antidiscrimination concept has developed in the two most influential areas where it has been used: antidiscrimination based upon nationality leading to the concept of European citizenship and antidiscrimination based upon sex, leading to a wider group of suspect classes protected under Community law.
\end{abstract}




\title{
ANTIDISCRIMINATION LAW IN THE EUROPEAN COMMUNITY
}

\author{
Erika Szyszczak*
}

\section{CONSTITUTIONAL VALUES}

The European political and legal community ("Community") is currently holding its breath, waiting and wondering if the Treaty of Lisbon 2007 ("Treaty" or "Reform Treaty") will ever be ratified by all twenty-seven Member States. ${ }^{1}$ The new Treaty is the consolidation of a decade of change in the European Union ("EU" or "Union") whereby a new balance between economic and social values has been recognized by the European Court of Justice and the political institutions. The Treaty of Lisbon in 2007 marks a significant change in the political and legal perception of the Union as being more than a market-oriented organization, recognizing a new polity that embraces a social model. Article 2 of the Treaty refers to the concept of a "social market economy" in which the Union is to address the sustainable development of Europe based upon balanced economic growth and price stability, a highly competitive social market economy aiming at full employment and social progress as well as a high level of protection and improvement of the quality of the environment. ${ }^{2}$ We see a discernible shift to recognizing a wider set of values within the constitutional base of the Union. This is highlighted by the ability of the Union to accede to the European Convention on Human Rights and Fundamental Freedoms ("ECHR") and to bestow legal status upon a Charter of Fundamental Rights of the Union. Thus, the European Social Model that is emerging from the Treaty of Lisbon 2007 is a mix of competition, free market, and solidarity based principles. Most importantly, Article 7 of the Treaty on the Functioning of the European Union ("TFEU") states:

* Jean Monnet Professor of European Law ad personam, University of Leicester, UK, Barrister, Littleton Chambers, UK. The author is grateful to the participants at the Conference "Fifty Years of European Community Law" held Feb. 29-Mar. 1, 2008 at Fordham University School of Law, New York.

1. See generally Draft Treaty of Lisbon (Reform Treaty), O.J. C 306/01 (2007), opened for signature Dec. 13, 2007 (not yet ratified) [hereinafter Reform Treaty].

2. See id. art. 3, at 8. 
The Union shall ensure consistency between its policies and activities, taking all of its objectives into account and in accordance with the principle of conferral of powers. ${ }^{3}$

Article 2 of the Treaty on European Union ("TEU"), as amended by the Treaty of Lisbon 2007, proclaims:

The Union is founded on the values of respect for human dignity, freedom, democracy, equality, the rule of law and respect for human rights, including the rights of persons belonging to minorities. These values are common to the Member States in a society in which pluralism, non-discrimination, tolerance, justice, solidarity and equality between women and men prevail. ${ }^{4}$

Article 10 of the TFEU, as created by the Treaty of Lisbon 2007, states:

In defining and implementing its policies and activities, the Union shall aim to combat discrimination based on sex, racial or ethnic origin, religion or belief, disability, age or sexual orientation. $^{5}$

Article 10 TFEU is found in Part II of the new Treaty under provisions that have a general application. It was a clause introduced by the 2004 Intergovernmental conference but at first sight appears aspirational rather than a concrete obligation.

This Article examines how an economic international Treaty arrangement in 1957, which was openly and unapologetically aimed at trade liberalization, arrived at including such fundamental social constitutional values in the Treaty of Lisbon 2007. This Treaty facilitates the constitutional framework for political and economic co-operation in the newly enlarged Union of twenty-seven Member States, setting the agenda for the next fifty years of European integration. In making this journey we will not be taking a nostalgic look backwards at the achievements of the Community, but we will examine how the groundwork was laid to lead what became the Union to recognize new forms of fundamental values capable of international recognition. This Article first examines the underlying sources for an antidis-

3. Consolidated Version of the Treaty on the Functioning of the European Union art. 7, O.J. C 115/47, at 53 (2008) [hereinafter TFEU].

4. Consolidated Version of the Treaty on European Union art. 2, O.J. C 115/13, at 17 (2008) [hereinafter TEU].

5. TFEU, supra note 3 , art. 10, O.J. C 115/47, at 53. 
crimination concept in Community law and then moves on to analyze how the antidiscrimination concept has developed in the two most influential areas where it has been used: antidiscrimination based upon nationality leading to the concept of European citizenship and antidiscrimination based upon sex, leading to a wider group of suspect classes protected under Community law.

The use of the term antidiscrimination law is a relatively new expression in the modern day European Community. ${ }^{6}$ The original Treaty Establishing the European Economic Community ("EEC Treaty") of 1957 referred to the concept of discrimination on the ground of nationality in Article $7 \mathrm{EEC}$, alongside limited references to non-discrimination in relation to transport,${ }^{7}$ agriculture, ${ }^{8}$ and taxation. ${ }^{9}$ The principle of non-discrimination and/or equality of treatment emerged as a general principle of Community law, and within this concept, as a fundamental right in Community law, extending its reach to many areas of economic activity where Community law applied, even though legislative competence may not have been transferred to the Community. ${ }^{10}$ One example of this is seen in the use of nondiscrimination and/or equality of treatment to develop the principle of effectiveness of Community law. The Community has very limited competence to legislate in the field of procedures

6. In deference to Roger Goebel's preference for the word "Community" over "Union" to describe the process of European integration, I have used the word Community in this article. See, e.g., Roger J. Goebel, Joining the European Union: The Accession Procedure for the Central European and Mediterranean States, 1 Loy. U. CHI. INT'L L. REv. 15, 15 (2004-05).

7. See Treaty Establishing the European Economic Community art. 75, Mar. 25, 1957, 298 U.N.T.S. 11 [hereinafter EEC Treaty].

8. Id. art. 34(3).

9. See Firma Fink-Frucht GmbH v. Hauptzollamt München-Landsbergerstrasse, Case 27/67, [1968] E.C.R. 223, at 232.

10. See Anthony Arnull, The European Union and its Court of Justice 459-511 (2006); Takis Tridimas, The General Principles of EU Law 40-88 (2006); John Usher, General Principles of EC LaW 16-20 (1998); see also Balkan-Imp.-Exp. GmbH v. HZA Berlin-Packhof, Case C-5/73 [1973] E.C.R. 1091 (using the principle of equality as a standard of review); Ruckdeschel \& Hansa-Lagerhaus Stroh v. HZA Hamburg-St. Annen, Joined Cases 177/76 \& 16/77, [1977] E.C.R. 1753, I 7 (wherein the Court enunciates the general principle of equality as a fundamental principle of Community law). The Court has also accepted that only like situations can be subject to the principle of equality and there may be objective reasons justifying differences in treatment. See, e.g., Milac GmbH v. HZA Freiburg, Case 8/78, [1978] E.C.R. 1721, I 18; Royal ScholtenHonig v. Intervention Bd., Joined Cases 103 \& 145/77, [1978] E.C.R. 2037; Cordorniu v. Council, Case C-30/89, [1994] E.C.R. I-1853. 
and remedies in the enforcement of Community law and has adhered to a principle of national procedural autonomy. Nevertheless, the Court has ruled that when applying national procedural rules to the enforcement of Community-based rights, national courts must ensure that the national rules are not less favorable than those governing similar domestic actions (principle of equivalence) and must not render practically impossible or excessively difficult the exercise of rights conferred by Community law (principle of effectiveness)..$^{11}$

The principle of non-discrimination has also found its way into principles of labor law; for example, the Court has ruled that potential applicants for Community posts must be treated equally, ${ }^{12}$ and free from discrimination (related to observance of religious holidays). ${ }^{13}$ The European Ombudsman has referred to this case law in recognizing the substantive equality of opportunity when applicants apply for posts. ${ }^{14}$ The principle is also seen as the basis for extending Community law rights to parttime workers ${ }^{15}$ and fixed-term workers. ${ }^{16}$ Similarly, the non-discrimination principle has been used to render stability to third country nationals who are legally residing in the Community. ${ }^{17}$

11. See Rewe-Zentralfinanz eGmbH v. Direktor der Landwirtschaftskammer Westfalen-Lippe, Case 39/73, [1973] E.C.R. 1039, I 5; Comet BV v. Produktschap voor Siergewassen, Case 45/76, [1976] E.C.R. 2043, II 13-16; Peterbroeck v. Belgium, Case C-312/93, [1995] E.C.R. I-4599, I 12; Unibet (London) Ltd v. Justitiekanslern, Case C432/05, [2007] E.C.R. I-2271, Il 43; Van der Weerd \& De Rooy \& Van Middendorp v. Minister van Landbouw, Natuur en Voedselkwaliteit, Joined Cases C-222/05 \& C-223/ 05 \& C-224/05 \& C-225-05, [2007] E.C.R. I-4233, I 28.

12. See Elkaim v. Commission, Case T-173/99, [2000] E.C.R. 1A 101, II-433.

13. See Prais v. Council, Case 130/75, [1976] E.C.R. 1589, I 16.

14. See generally Decision of the European Ombudsman on Complaint 3346/2004/ ELB Against the European Personnel Selection Office, http://www.euro-ombudsman. eu.int/decision/en/043346.htm; Decision of the European Ombudsman on Complaint 3278/2004/ELB Against the European Parliament, http://ombudsman.europa.eu/ decision/en/043278.htm.

15. See Council Directive No. 97/81/EC, O.J. L 14/9 (1998), Il 11.

16. See generally Council Directive No. 1999/70/EC, O.J. L 175/43 (1999); see also Impact v. Minister for Agriculture and Food et al., Case C-268/06 (ECJ Apr. 15, 2008) (not yet reported) (holding that public sector employees can rely on the direct effect of the non-discrimination principle found in Clause 4 (1) of the Framework Agreement since the Framework Agreement is an integral part of the Directive to which it is annexed).

17. See generally Council Directive No. 2003/109/EC, O.J. L 16/44 (2004). 


\section{INFLUENTIAL SOURCES OF THE PRINCIPLE OF NON- DISCRIMINATION IN THE UNION}

Many of the international and regional human rights treaties that have attracted the signature and participation of the Member States have included antidiscrimination and equality clauses. ${ }^{18}$ The Community has also been at the forefront of the 1995 Beijing Conference on Women. These international fora form part of the cultural heritage of fundamental rights which have influenced the decisions of the European Courts in antidiscrimination disputes and formed part of the basis of the written Charter of Fundamental Rights of the EU. ${ }^{19}$ The European Court of Justice ("ECJ" or "Court") has also drawn upon these sources in developing its general principles of Community law. ${ }^{20}$ Likewise, the Court has referred to national constitutions ${ }^{21}$ as sources for fundamental rights and, in the modern era, with developments in networking, it is easier for the Community and national legal systems to communicate directly regarding the development of antidiscrimination law. ${ }^{22}$

18. See generally Yota Kravaritou, Equality Between Men and Women (Article 23), in European Labor LaW and the EU Charter of Fundamental Rights (Brian Bercusson ed., 2002).

19. See generally Economic and Social Rights Under the EU Charter of Fundamental Rights: A Legal Perspective (Tamara K. Hervey \& Jeff Kenner eds., 2003); Explanations Relating to the Charter of Fundamental Rights, O.J. C 303/17 (2007). The Charter was proclaimed by the European Parliament, the Council and the Commission on December 12, 2007. Once the Treaty of Lisbon 2007 is ratified, the Charter will have legally binding status, but will not be incorporated into the Treaty on European Union ("TEU") or the Treaty on the Functioning of European Union ("TFEU"). The Advocates General have referred to the Charter in their Opinions; however, the Court has referred to it infrequently and to date has not upheld a substantive fundamental right. See, e.g., Parliament v. Council, Case C-540/03, [2006] E.C.R. I-5769, I 4; Advocaten voor de Wereld VZW v. Leden van de Ministerraad, Case C-303/05, [2007] E.C.R. I-3633, I 46; Unibet (London) Ltd v. Justitiekanslern, Case C-432/05, [2007] E.C.R. I-2271, II 37; Int'l Transp. Workers' Fed'n v. Viking Line ABP, Case C-438/05, [2007] E.C.R. I-10779, I 43; Promusicae v. Telefónica de España SAU, Case C-275/06, slip op., I 1 (ECJ Jan. 29, 2008) (not yet reported); Dynamic Median Vertriebs GmbH v. Avides Media AG, Case C-244/06, slip op., I 41 (ECJ Feb. 14, 2008) (not yet reported).

20. See, e.g., Defrenne v. Sabena (No. 3), Case 149/77, [1978] E.C.R. 1365, II 27 28 (referencing the European Social Charter and International Labor Organization ("ILO") Conventions); Nold v. Commission, Case 4/73, [1974] E.C.R. 491, I 13 (referencing the Convention for the Protection of Human Rights and Fundamental Freedoms ("ECHR")); Orkem v. Commission, Case 374/87, [1989] E.C.R. 3283, I 18 (referencing the U.N. International Covenant on Civil and Political Rights).

21. See Hauer v. Land Rheinland-Plafz, Case 44/79, [1979] E.C.R. 3727, II 3-5.

22. See generally Cases Materials and Text on National, Supranational and InTERnational NoN-Discrimination Law (Dagmar Schiek et al. eds., 2007). 


\section{INTERNATIONAL CONVENTIONS AS A SOURCE OF COMMUNITY LAW}

The most influential set of international conventions that have been sources of antidiscrimination law for the Community include the International Covenant on Civil and Political Rights (1966), the Convention on the Elimination of All Forms of Racial Discrimination (1966), the Convention on the Political Rights of Women (1953), along with the 1979 Convention on the Elimination of All Forms of Discrimination Against Women and the Convention on the Rights of the Child (1989). Equally there are a number of influential Declarations: the Declaration of the Rights of the Child (1959), the Declaration on the Elimination of Discrimination against Women (1967), the Declaration on the Rights of Disabled Persons (1975) and the Declaration on the Elimination of All Forms of Intolerance and of Discrimination Based on Religion or Belief (1981).

The International Labour Organization ("ILO") has played a prominent role in developing the principle of non-discrimination in the field of employment. In its earliest Constitution of 1919, the right to equal treatment was recognized. Further examples of the antidiscrimination principle are found in the Preamble, which refers to the need for recognition of the principle of equal remuneration for work of equal value, a forerunner of the present equal pay for work of equal value clause, currently found in Article 141 of the Consolidated Version of the Treaty Establishing the European Community ("EC" or "EC Treaty"). ${ }^{23}$ Later amendments to the Constitution, such as the 1944 Declaration of Philadelphia, which was incorporated into the ILO Constitution, affirmed that the principle of non-discrimination is intended to be "fully applicable to all peoples everywhere . . . ."24 This can also be seen in Article 2 of the Declaration of Philadelphia:

[A]ll human beings, irrespective of race, creed or sex, have the right to pursue both their material well-being and their spiritual development in conditions of freedom and dignity,

23. See Constitution of the International Labor Organization ("ILO"), pmbl., 1944 [hereinafter ILO Constitution], available at http://training.itcilo.it/ILS/foa/library/ constitution/iloconst_en.html\#annex; Consolidated Version of the Treaty Establishing the European Community, art. 141, O.J. C 321 E/37 (2006) [hereinafter EC Treaty].

24. ILO Constitution, Declaration Concerning the Aims and Purposes of the International Labor Organization, Annex, art. V [hereinafter Declaration of Philadelphia]. 
of economic security and equal opportunity. ${ }^{25}$

Over time, the ILO has moved towards recognizing a set of fundamental principles in the ILO Declaration on Fundamental Principles and Rights at Work 1998. ${ }^{26}$ Two Conventions are central to these principles: the Equal Remuneration Convention Number 100 in 1954 and the Employment and Occupation Convention Number 111 in $1958 .{ }^{27}$ Convention Number 122, the Employment Policy Convention of 1964 , is also regarded as a "priority Convention" that States are urged to ratify because of its role in the functioning of international labor markets. More recently Conventions have focused on part-time work and domestic work, areas where the Community has also attempted regulation. ${ }^{28}$

\section{REGIONAL CONVENTIONS}

In the international arena, we have seen the emergence of a more focused development of European regional human rights norms. These too have played a role in the ECJ's case law and the creation of the written Charter of Fundamental Rights. ${ }^{29}$ The most influential European source of rights for antidiscrimination measures and reliance on case law is the Convention for the Protection of Human Rights and Fundamental Free-

25. Id. art. 2.

26. See Erika Szyszczak, EC Labor Law 77-106 (2000); see generally Bob Hepple, Labor laws and Global Trade (2005); see also Bob Hepple, Rights at Work: Global, European and British Perspectives 57 (2005)

27. However, there are many Conventions that impact the realization of antidiscrimination as a principle. See, e.g., Convention (No. 156) concerning Equal Opportunities and Equal Treatment for Men and Women Workers with Family Responsibilities, Aug. 11, 1983, available at http://portal.unesco.org/shs/en/ev.php-URL_ID=4193\& URL_DO=DO_PRINTPAGE\&URL_SECTION=201.html; Maternity Protection Convention (No. 183), June 15, 2000, available at www.ilo.org/ilolex/english/reportforms/ pdf/22e183.pdf; Vocational Rehabilitation and Employment (Disabled Persons) Convention (No. 159), June 20, 1983, available at http://www.ilo.org/ilolex/cgi-lex/ convde.pl?C159; Equality of Treatment (Accidents Compensation) Convention (No. 19), June 5, 1925, available at http://www.ilo.int/ilolex/cgi-lex/pdconv.pl?host=status $01 \&$ textbase $=$ iloeng\&document $=20 \&$ chapter $=1 \&$ query $=\% 23$ subject $\% 3 D 13 \&$ highlight $=$ \&querytype=bool\&context=0; Equality of Treatment (Social Security) Convention (No. 118), June 28, 1962, available at http://www.ilo.org/ilolex/cgi-lex/convde.pl?C1 18.

28. See, e.g., Part-time Work Convention (No. 175), June 24, 1994, available at http://www.ilo.org/ilolex/cgi-lex/convde.pl?C175; Home Work Convention (No. 177), June 20, 1996, available at http://www.ilo.org/ilolex/cgi-lex/convde.pl?C177.

29. See, e.g., Nold v. Commission, Case 4/73, [1974] E.C.R. 491. 
doms. ${ }^{30}$ Article 14 ECHR contains a wide-ranging obligation:

The enjoyment of the rights and freedoms set forth in this Convention shall be secured without discrimination on any ground such as sex, race, color, language, religion, political or other opinion, national or social origin, association with a national minority, property, birth or other status. ${ }^{31}$

All of the Member States are signatories of the European Convention on Human Rights. Article 14 ECHR covers similar grounds as Article $13 \mathrm{EC}$, but also extends its protection to discrimination on grounds of birth status. ${ }^{32}$ Also, Article 14 ECHR is limited insofar as it can only be invoked when used in conjunction with a substantive ECHR right, including rights contained in the Protocols to the ECHR. ${ }^{33}$ In recent years this limitation has been ameliorated by the introduction of Protocol 12, adopted in June 2000 and entering into force on April 1, 2005, which creates a free standing antidiscrimination provision for those Member States which have ratified the Protocol. ${ }^{34}$ Article 1 declares:

General prohibition of discrimination

1. The enjoyment of any right set forth by law shall be secured without discrimination on any ground such as sex, race, color, language, religion, political or other opinion, national or social origin, association with a national minority, property, birth or other status.

2. No one shall be discriminated against by any public authority on any ground such as those mentioned in paragraph $1 .^{35}$

The European Social Charter ("ESC") ${ }^{36}$ has assumed greater sig-

30. Convention for the Protection of Human Rights and Fundamental Freedoms, Nov. 4, 1950, 213 U.N.T.S. 221 [hereinafter ECHR].

31. Id. art. 14.

32. See id.; EC Treaty, supra note 23 , art. 13, O.J. C 321 E/37.

33. See ECHR, supra note 30, Protocols.

34. See id. Protocol No. 12. At the time of writing (June 2008), only six of the Member States had ratified Protocol No. 12: Cyprus, Finland, Luxembourg, The Netherlands, Romania, and Spain. See Claudia Tavani, Keeping the Criminality Myth Alive: Stigmatisation of Roma through the Italian Media, European Roma Rights Centre, http:// www.errc.org/cikk.php?cikk=2168 (explaining that Italy has not yet ratified Protocol 12 of the ECHR).

35. ECHR, supra note 30 , art. 1.

36. See generally European Social Charter, Oct. 18, 1961, 529 U.N.T.S. 89 [hereinafter ESC]; David Harris \& John Darcy, The European Social Charter: The Protection of Economic and Social Rights in Europe (2001). 
nificance as a result of its mention in ECJ judgments ${ }^{37}$ and reference to it in the Charter of Fundamental Rights of the European Union. ${ }^{38}$ However, the ratification of the ESC has been mixed across the EU. The ESC, which was signed in 1961, aims to protect a wide range of social rights. Therefore, its coverage was much greater than the comparable attempts at the EU level. The focus of protection has been upon employment, education, housing, social security, and healthcare, but the original ESC only mentioned non-discrimination in its Preamble. The later version of the ESC, signed in 1996, changed this focus, drawing upon Article 14 ECHR. Article E of the ESC states:

[T] he enjoyment of the rights set forth in this Charter shall be secured without discrimination on any ground such as race, color, sex, language, religion, political or other opinion, health, association with a national minority, birth or other status. ${ }^{39}$

The increased prominence of the ESC has sprung from the growing practice of non-governmental organizations ("NGOs") and trade unions to instigate collective claims ${ }^{40}$ under the ESC; creating a new form of "case law" on discrimination. ${ }^{41}$

At the practical level, the Community does not work in isolation and is receptive to developments in antidiscrimination concepts at the national and international levels. However, the overlapping of the individual litigant and the representative litigant, for example a nongovernmental organization, is faced not only with polycentric decision-making when trying to influence policy development but also a choice of legal fora for concurrent ave-

37. In fact, the European Court of Justice ("ECJ") referred to the European Social Charter ("ESC") in its early case law on fundamental rights in the Defrenne v. Sulena litigation. See Defrenne v. Sabena, Case 149/77, [1978] E.C.R. 1365, Il 28.

38. See Mark Bell, Walking in the Same Direction? The Contribution of the European Social Charter and the European Union to Combating Discrimination, in Social RucHTS iN EUROPE 261, 268 (Gráinne de Búrca \& Bruno de Witte eds., 2005); see generally Gerard Quinn, The European Social Charter and EU Antidiscrimination Law in the Field of Disability: Two Gravitational Fields with One Common Purpose, in Social Rights IN Europe 279 (Gráinne de Búrca \& Bruno de Witte eds., 2005).

39. ESC, supra note $36, \mathrm{Pt} . \mathrm{V}$, art. E.

40. See Mark Bell, Combating Discrimination through Collective Complaints under the European Social Charter, 3 Eur. ANTI-Discrimination L. Rev. 13, 13 (2006).

41. One of the most important break-through cases is a decision against France finding that insufficient resources had been provided for the education of children and adults with autism to establish discrimination on the grounds of disability. See generally Autism-Europe v. France, Complaint No. 13/2002, Nov. 4, 2003. 
nues of litigation. On the one hand, such opportunities for action may be beneficial, for example a recent decision of the European Court of Human Rights ("ECHR Court") on segregation in the schooling of Roma children, D.H. v. Czech Republic, drew heavily on international conventions and the Community case law on antidiscrimination to find statistical evidence showing that a Roma child was twenty-eight times more likely to be educated in a school for children with learning disabilities. ${ }^{42}$ This was a form of discrimination outlawed by the ECHR. The ruling is a landmark judgment in terms of advancing the undeveloped jurisprudence on race and ethnic discrimination under Community law, the use of statistical evidence in proving discrimination, as well as opening up the possibilities of using the ECHR in other areas. ${ }^{43}$

On the other hand the competing choice of fora may stretch resources when trying to operate on so many legal and political fora. Pursuing different legal strategies may result in different legal outcomes and may not provide a holistic remedy for the individual. ${ }^{44}$ Similarly the lack of coordination between NGOs in Europe may result in different priorities with competing policies being pursued with the national governments and the political supra-national institutions.

42. D.H. v. Czech Republic, Application 5732/00, slip op., If 45 (Eur. Ct. H.R., judgment delivered Nov. 14, 2007) (not yet reported) (known as the "Ostrava" case).

43. See generally Olivier de Schutter \& Julie Ringelheim, Ethnic Profiling: A Rising Challenge to European Human Rights Law, 71 MoD. L. REv. 358 (2008).

44. See generally Nicholas Bamforth, Prohibited Grounds of Discrimination Under EU Law and the European Convention on Human Rights: Problems of Contrast and Overlap, CAMBRIDGE Y.B. EUR. L. 1 (2006-07) (comparing Community law and ECHR law on antidiscrimination). Bamforth concludes that Community law can be directly effective and be used to disapply national legislation, whereas ECHR rights are not directly effective and what is required by means of a remedy is a flexible notion of an "adequate remedy." The ECHR allows for new categories of discrimination to be read into Article 14 ECHR, whereas Community law does not offer the same opportunities (at least in relation to Article 13 Treaty Establishing the European Community ("EC" or "EC Treaty"). There are differences between the two systems on the kinds of norms and acts which may be subject to review. The ECHR contains a "margin of appreciation" principle which has no direct correlation in Community law. Community law has long recognized a concept of indirect discrimination but this has only recently been recognized in the ECHR. There are differences in the way the ECJ and the ECHR Court interpret the principles of proportionality and justification. The 2007 Treaty of Lisbon facilitates the accession of the European Union ("EU") to the ECHR and, if this occurs, differences between the two fundamental rights regimes may be ameliorated. 


\section{ANTIDISCRIMINATION ON THE GROUNDS OF NATIONALITY}

Antidiscrimination on the grounds of nationality has been described by Takis Tridimas as the "keystone of integration." 45 The principle of non-discrimination on grounds of nationality was found primarily in the free movement provisions of Article 48(2), 52, and 60 of the EEC and Regulation 1612/68/EEC. ${ }^{46}$ The ECJ recognized both direct and indirect discrimination, the latter creating a new basis on which sex discrimination concepts could later move away from formal notions of equality to substantive forms of equality. In its case law the ECJ used the nondiscrimination on ground of nationality provision to create the early notions of "citizenship" that later found expression in the interpretation of the Citizenship provision of Article $18 \mathrm{EC}$, combined with the non-discrimination on grounds of nationality provision now found in Article 12 EC. ${ }^{47}$ Much of the early case law on the free movement of goods used discrimination as the basis for the finding that a national measure was a hindrance to interstate trade. ${ }^{48}$ Thus, the economic nature of the non-discrimination principle is openly recognized by Advocate General Jacobs in his Opinion in Phil Collins v. Imtrat Handelsgessellschaft $m b H,{ }^{49}$ where he states that:

The prohibition of discrimination on grounds of nationality is the single most important principle of Community law. It is the leitmotiv of the EEC Treaty. ${ }^{50}$

45. Takis Trudimas, The General Principles of EU Law 76 (2d ed. 2006).

46. See EEC Treaty, supra note 7, arts. 48(2), 52, 60; Commission Regulation No. 1612/68/EEC, O.J. L 257/2 (1968).

47. See, e.g., Cowan v. Trésor Public, Case 186/87, [1989] E.C.R. 195; Forcheri v. Belgium, Case 152/82, [1983] E.C.R. 2323; Gravier v. City of Liege, Case 293/83, [1985] E.C.R. 593; Data Delecta Aktiebolag v. MSL Dynamics Ltd, Case C-43/95, [1996] E.C.R. I-4661, II 16-17; Weiser v. Caisse Nationale des Barreaux Français, Case C-37/ 89, [1990] E.C.R. I-2395, I 6 (equal treatment was not necessarily limited to nationality).

48. See G. Marenco, Pour une Interprétation Tradionnelle de la Notion de Mesure d'Effet Equivalent à une Restriction Quantitative, $20 \mathrm{CDE}(1984)$, at 291; see also Procureur du Roi v. Dassonville, Case C-8/74, [1974] E.C.R. 837; Union Royale Belge Des Societes De Football Association (ASBL) v. Bosman, Case C-415/93, [1995] E.C.R. I-4921, II 117, 146 (wherein the European Court of Justice moved beyond a non-discrimination principle to review measures which are or may be a hindrance to trade).

49. See Phil Collins v. Imtrat Handelsgesellschaft mbH, Joined Cases C-92/92 \& C326/92, [1993] E.C.R. I-5145.

50. Opinion of Advocate General Jacobs, Phil Collins v. Imtrat Handelsgesellschaft mbH, Joined Cases C.92/92 \& C-326/92, [1993] E.C.R. I-5145, II 9. 
Advocate General Jacobs also sees a social side to the principle in that it is part of an embryonic citizenship whereby citizens have common aspirations as well as rights. In a later case Advocate General Jacobs stated:

Freedom from discrimination on grounds of nationality is the most fundamental right conferred by the Treaty and must be seen as a basic ingredient of Union citizenship. ${ }^{51}$

The ECJ has taken a mixed response to the principle of discrimination on the grounds of nationality. The ECJ refused to recognize the idea of reverse discrimination whereby its own nationals could be placed in a worse position than nationals of another Member State who had exercised their rights to free movement. ${ }^{52}$ The concept of non-discrimination was limited in promoting market integration, with the ECJ moving beyond the concept of antidiscrimination on the grounds of nationality to protect the right to free movement generally ${ }^{53}$ and to recognize a general right of access to economic activity that can trigger Community law. ${ }^{54}$ It was also the ECJ that limited the potentially wide application of this measure which could have addressed issues of race discrimination, alongside ethnic and minority rights discrimination, instead limiting it to protect only nationals of one of the Member States of the EEC, and later nationals covered by one of the external Treaty arrangements made with third states which allowed for access to the EEC market of goods or persons. ${ }^{55}$ This limited approach emphasized the significance of being a "privileged" citizen by holding the nationality of one of the Member States when later using the new "citizenship" provisions introduced by the 1992 Treaty on the European Union

51. Opinion of Advocate General Jacobs, Bickel \& Franz, Case C-274/96, [1998] E.C.R. I-7637, I 24.

52. See, e.g., Morson v. Netherlands, Joined Cases 35-36/82, [1982] E.C.R. 3723.

53. See, e.g., Corsica Ferries Italia Srl v. Corpo dei Piloti del Porto di Genova, Case C-18/93, [1994] E.C.R. I-1783; D'Hoop v. Office National de l'Emploi, Case C-224/98, [2002] E.C.R. I-98, II 15-16; Köbler v. Austria, Case C-224/01, [2003] E.C.R. I-10239, I 77.

54. See generally Union Royal Belge des Sociétés de Football Association (“ASBL”) v. Bosman, Case C-415/93, [1995] E.C.R. 1-4921; see also Commission v. Denmark, Case C-464/02, [2005] E.C.R. 7929, II 34-36.

55. See Steve Peers, Towards Equality: Actual and Potential Rights of Third-Country Nationals in the European Union, 33 CоммоN Mкт. L. REv. 7, 21-24 (1996). Note that the agreements with Turkey, Morocco, and Algeria have been the major sources of litigation. 
(also known as the Maastricht Treaty). ${ }^{56}$ The ECJ used Article $12 \mathrm{EC}$ in conjunction with Article $18 \mathrm{EC}$ to create a core European "citizenship" right. ${ }^{57}$ In Grzelczyk $v$. Centre Public d'Aide Sociale d'Ottignies-Louvain-la-Neuve (CPAS) the Court proclaimed:

Union citizenship is destined to be the fundamental status of nationals of the Member States. ${ }^{58}$

\section{CITIZENSHIP}

Citizenship is the most dynamic and evolving aspect of antidiscrimination on the grounds of nationality. Non-discrimination is an essential component of the citizenship idea that has emerged from Articles 12, 17, and 18 EC and the Citizen's Rights Directive. ${ }^{59}$ The core of the citizenship right is the right to free movement between, and within, the Member States and the right to equal treatment with host state nationals. The principle embraces both direct and indirect discrimination ${ }^{60}$ and extends beyond immigration rights to cover equal treatment in respect to social and welfare benefits. ${ }^{61}$ These essential economic rights underpin the fundamental freedoms and values of the original Common Market. ${ }^{62}$ More recently the Court has refined the concept of non-discrimination in that it extends to cover discrimination on the grounds that a citizen has exercised the right to free movement. ${ }^{63}$ The right extends not only to nationals of the Member States but also gives limited rights to their

56. Treaty on European Union, O.J. C 191/1 (1992).

57. See generally Martínez Sala v. Freistaat Bayern, Case C-85/96, [1998] E.C.R. 2691.

58. Grzelczyk v. Centre Public d'Aide Sociale d'Ottignies-Louvain-la-Neuve (CPAS), Case C-184/99, [2001] E.C.R. 6193, If 31.

59. Compare EC Treaty, supra note 23 , arts. 17, 12, 18 O.J. C $321 \mathrm{E} / 37$, with the Council Directive No. 2000/43/EC, art. 3(2), O.J. L 180/22, at 24 (2000) ("This Directive does not cover difference of treatment based on nationality . ...").

60. See Sotgiu v. Deutsche Bundespost, Case 152/73, [1974] E.C.R. 153, II 11; see also O'Flynn v. Adjudication Officer, Case C-237/94, [1966] E.C.R. 2617, I 17; Groener v. Minister for Educ., Case 379/87, [1989] E.C.R. 3967. The legitimacy of a discriminatory policy relies on the principle of proportionality. In Groener $v$. Minister for Education, for example, a language requirement for school teachers was justified as a legitimate cultural policy. See Groener, [1989] E.C.R. 3967, II 19.

61. See Martínez Sala, [1998] E.C.R. 2691, I 63.

62. See Angonese v. Cassa di Risparmio di Bolzano SpA, Case C-281/98, [2000] E.C.R. 4139, I 45 (noting that the principle of non-discrimination applies not only to the Member States but also to employers).

63. See D'Hoop v. Office national de l'emploi, Case C-224/98, [2002] E.C.R. 6191, II 34-36; see also Volker Graf v. Filzmoser Maschinenbau GmbH, Case C-190/98, [2000] 
dependants irrespective of their nationality. ${ }^{64}$ It is also limited since real opportunities for integration into the receiving Member State may also entail positive measures to make that right a reality.

\section{THE LEGAL FRAMEWORK FOR ANTIDISCRIMINATION LEGISLATION}

The most developed area of antidiscrimination law is the development of the principle in relation to non-discrimination, first developed in relation to gender discrimination, and now, by virtue of Article $13 \mathrm{EC}$, extended to the suspect classes of race, sexual orientation, age, religion or belief, and disability. ${ }^{65}$ This is not an exhaustive list and does not include the contentious classes of "social" or "birth" status.

The idea of antidiscrimination in the EU has developed primarily through case law and embraces a range of concepts and ideas of non-discrimination, equal treatment, equality, as well as a duty of mainstreaming equal opportunities policies through all Community policies. While litigation raises issues of substance and substantive law, the antidiscrimination principle on grounds of sex extends also to policy-making (including the use of soft law and the open method of co-ordination ("OMC") used in the Lisbon process), the role of procedures, enforcement and remedies.

Article 119 EEC, the bedrock on which the gender antidiscrimination principle has emerged, did not refer to antidiscrimination but referred to the principle of "equal pay for equal work," amended to include the principle of "equal pay for work

E.C.R. 493; Pusa v. Osuuspankkien Keskinainen Vakuutusyhtio, Case C-224/02, [2004] E.C.R. 5763, I 18.

64. See Carpenter v. Sec'y of State for the Home Dep't, Case C-60/00, [2002] E.C.R. 627, I 38 (“[T] he Community legislature has recognized the importance of ensuring the protection of the family life of nationals of the Member States in order to eliminate obstacles to the exercise of the fundamental freedoms guaranteed by the Treaty ...."); see also Zhu v. Sec'y of State for the Home Dep't, Case C-200/02, [2004] E.C.R. 9925; Sec'y of State for the Home Dep't v. Akrich, Case C-109/01, [2003] E.C.R. I-9607; Jia v. Migrationsverket, Case C-1/05, [2007] E.C.R. 1. However, the right does not extend to reverse discrimination when there is no link with the exercise of a Community law right. See, e.g., Uecker v. Land-Nordrhein-Westfalen, Joined Cases C-64/96 \& C-65/96, [1997] E.C.R. 3171, I 23; Garcia Avello v. Belgium, Case C-148/02, [2003] E.C.R. 11613, I 26. But see Nerkowska v. Zakład Ubezpieczeń Spolecznych Oddzial w Koszalinie, Case C-499/06 (ECJ May 22, 2008) (not yet reported).

65. See EC Treaty, supra note 23, art. 3(2), O.J. C 321 E/37. 
of equal value" by the Treaty of Amsterdam 1997 (now Article 141 EC). ${ }^{66}$ Through the Court's case law the concept was elevated to a fundamental right and continues to be seen as one of the foundations of the Community. ${ }^{67}$ Article 119 EEC, was initially and essentially a competition law provision stating a principle of equal pay for equal work. It was included at the insistence of France to prevent Member States without such a social clause using cheap female labor to undercut the more progressive Member States who did have such a clause. ${ }^{68}$ Noticeably it did not include the wider ILO concept of equal pay for work of equal value. The equal pay for equal work principle was developed by the Court in a series of test cases involving Defrenne $v$. Sabena. ${ }^{69}$ The Court set out a number of basic principles which have survived and evolved and formed the basis for a wider platform of non-discrimination rights. These include the doctrine of horizontal direct effect, the fact that sex equality is a fundamental right of Community law, the application of Article 119 EC to all forms of pay discrimination, including discrimination found in collective agreements and legislation.

In 1997, Article 119 EEC was revised to accommodate the body of case law that had emerged. In the form of Article 141 $\mathrm{EC}$, it expanded to include the concept of "equal pay for work of equal value," to create a legal base to develop further antidiscrimination measures and to allow the permissive use of positive action. $^{70}$

The creation of a legal base for further antidiscrimination measures was potentially an important symbolic move since the political thrust to widen the ambit of antidiscrimination protection was limited by the need to use either the legal base of the Internal Market, Article $94 \mathrm{EC}$, or the broad residual legal base

66. See id. art. 141; Treaty of Amsterdam amending the Treaty on European Union, the Treaties establishing the European Communities and certain related acts art. 141, O.J. C 340/1 (1997) [hereinafter Treaty of Amsterdam].

67. See, e.g., Brunnhofer v. Bank der Österreichischen Postsparkasse AG, Case C381/99, [2001] E.C.R. 496, II 28.

68. See generally Erika Szyszczak, Pay Inequalities and Equal Value Claims, 48(2) MoD. L. REv. 139 (1985) (account of the early history of Article 119 Treaty Establishing the European Economic Community ("EEC Treaty" or "EEC")).

69. On the background of the test case strategy, see Catherine Hoskyns, INTEgrating Gender: Women, Law and Politics in the European Union 90-93 (1996) and Erika Szyszczak, EC Labor Law (2000) (on the lasting impact of the cases).

70. See EC Treaty, supra note 23, art. 141, O.J. C 321 E/37; EEC Treaty, supra note 7 , art. 119. 
of Article 308 EC with both measures requiring unanimous agreement in the Council. Thus beginning with the second Defrenne case until 1997 only five pieces of secondary legislation were adopted: a Directive on equal pay, ${ }^{71}$ a Directive on equal treatment, ${ }^{72}$ a Directive on equality in social security, ${ }^{73}$ a Directive on occupational social security ${ }^{74}$ and a Directive addressing equal treatment for the self-employed. ${ }^{75}$ In 2004 a new Directive was adopted addressing access to the supply of goods and services. ${ }^{76}$ The legislation and case law was consolidated and brought together in a functional manner in a re-casting Directive, European Parliament and Council Directive 2006/54/EC. ${ }^{77}$ From these rather meager legal bases the Court was able to create evolving generations of case law addressing, not only substantive legal rights and concepts, but also procedural rights and ideas of effective sanctions and remedies. ${ }^{78}$ In 1995 , the United Nations Women's Conference in Beijing called for the use of gender mainstreaming ${ }^{79}$ and the Community quickly addressed this call in a Communication from the Commission in $1996^{80}$

71. Council Directive No. 75/117/EEC, O.J. L. 45/19 (1975).

72. Council Directive No. 76/207/EEC, O.J. L 39/40 (1976). In 2002, this Directive was revised to bring it up to date with the Court's case law. See Council Directive No. 2002/73/EC, O.J. L 269/15 (2002).

73. Council Directive No. 79/7/EEC, O.J. L 6/24 (1979).

74. Council Directive No. 86/378/EEC, O.J. L 225/40 (1986).

75. Council Directive No. 86/613/EEC, O.J. L 359/56 (1986).

76. Council Directive No. 2004/113/EC, O.J. L. 373/37 (2004); see generally Eugenia di Caracciolo di Torella, The Goods and Services Directive: Limitations and Opportunities, 13 Feminist Legal Stud. 337 (2005).

77. See generally Council Directive No. 2006/54/EC, O.J. L 204/23 (2006). The old texts remain in force until 2009. Burrows and Robinson note that the political recasting missed an opportunity to recast the equal opportunities/antidiscrimination policy into a human rights concept as well. See generally Noreen Burrows \& Muriel Robinson, An Assessment of the Recast of Community Equality Laws, 13 Eur. L.J. 186 (2007). (2003).

78. See generally Jonas Malmberg et al., Effective Enforcement of EC Labor LaW

79. Gender mainstreaming has been defined by the Council of Europe as: "the (re)organization, improvement, development and evaluation of policy processes, so that a gender equality perspective is incorporated in all policies at all levels and at all stages, by actors normally involved in policy-making." Council of Europe, Group of Specialists on Mainstreaming, Final Report: Gender Mainstreaming: Conceptual Framework, Methodology and Presentation of Good Practices, Pt. I, $\$ 3$ (May 1998), available at http:// www.gendermainstreaming-planungstool.at/_lccms_downloadarchive/00003/Europa rat.pdf.

80. See generally Commission of the European Communities, Incorporating Equal Opportunities for Women and Men into All Community Policies and Activities, COM (96) 67 Final (Feb. 1996). 
and in the 1997 Treaty of Amsterdam by introducing Article 3(2) EC. The use of mainstreaming has received mixed responses, from those who see it as a significant policy tool ${ }^{81}$ to those who argue it masks the use of more pro-active measures in favor of women. ${ }^{82}$

Each piece of legislation was agreed by consensus only by creating exemptions for sensitive areas, most notably equality in social security issues, differences in state pension ages, the special protection of maternity provisions for women and provisions relating to positive action and protective legislation. This hard law, however, was merely the tip of the iceberg. Accompanying and under-pinning the legislation was a plethora of soft law in the form of Action Plans, Resolutions, and Recommendations moving towards more recent ideas of Roadmaps ${ }^{83}$, Framework Strategies, ${ }^{84}$ and the European Pact for Gender Equality (2006), culminating in the designation of the year 2007 as the European Year of Equal Opportunities for All. Using "softer" techniques the Community has resulted in the penetration into a number of areas of non-economic activity which would normally be within the domain of Member State competence, particularly in policies relating to domestic violence and women's health. It has allowed a gentle transition from a focus upon labor law rights to labor market policies and a focus upon reconciliation of work and family life measures. Arguments have been made that the transnational policy learning and exchange of experience under the Antidiscrimination Action Programme has created a horizontal learning program that has led to the Europeanization of antidiscrimination policies. ${ }^{85}$ In 2007 a European Institute for Gender Equality was established by a European Parliament and Council Regulation, its purpose being to support legislative and

81. See generally Mark. A. Pollack \& Emile Hafner-Burton, Mainstreaming Gender in the European Union, 7 J. EUR. PUB. PoL'y 432 (2000).

82. See generally Maria Stratigaki, Gender Mainstreaming vs Positive Action: An Ongoing Conflict in EU Gender Equality Policy, 12 Eur. J. WOMEN's STud. 165 (2005).

83. See generally Commission of the European Communities, A Roadmap for Equality Between Women and Men 2006-2010, COM (2006) 92 Final (Mar. 2006).

84. See generally Commission of the European Communities, Towards a Community Framework Strategy on Gender Equality (2001-2005): Proposal for a Council Decision on the Programme Relating to the Community Framework Strategy on Gender Equality (2001-2005), COM (2000) 335 Final (June 2000).

85. See Mark Bell, The Implementation of European Antidiscrimination Directives: Convenging Towards A Common Model?, 79 POL. Q. 36, 41 (2008). 
policy initiatives at the EU and national level. ${ }^{86}$

Gender issues have figured prominently in the OMC policies which emerged from the Treaty of Amsterdam 1997. Equal Opportunities formed one of the first four pillars of the first set of Employment Guidelines and gender was integrated (mainstreamed) through the other three pillars in the OMC processes. ${ }^{87}$ As a result the promotion of gender became a key objective of the OMC with a number of specific equality targets being set, for example, the female employment rate and the provision of childcare. ${ }^{88}$ However in the mid-term review of the OMC in 2005, gender equality disappeared as a special pillar and the objective of equal opportunities between men and women was reduced to one guideline. ${ }^{89}$

Given the increased participation of women in paid work in the labor market and the international dimension to feminist politics it is understandable from both a political and economic perspective why gender antidiscrimination measures were given so prominent a place in the early general principles of Community law and the social policies pursued by the Community. At the national, European, and international levels, other suspect classes looked on in envy at the evolving sex discrimination provisions and case law and fought for the right to the same protection as gender in Community law. From the 1980s onwards the Community took a greater interest in immigration matters, tempered by a human rights perspective, on combating the rising incidents of racism and xenophobia in Europe.$^{90}$ The Treaty of Amsterdam 1997 ushered in an important change, the inclusion of a new Article $13 \mathrm{EC}$ which significantly enhanced the suspect

86. See Council Regulation No. 1922/2006, art. 2, O.J. L 403/9, at 11 (2006).

87. See generally Fiona Beveridge, Building Against the Past: The Impact of Mainstreaming on EU Gender Law and Policy, 32 ELR. L. REv. 193 (2007).

88. See generally Gender and the Open Method of Coordination (Fiona Beveridge \& Samantha Velluti eds., 2008).

89. See generally European Commission, Report from the High Level Group Chaired by Wim Kok, Facing the Challenge: The Lisbon Strategy for Growth and Employment (Nov. 2004), available at http://ec.europa.eu/growthandjobs/pdf/kok_report_en.pdf. The review led to the creation of the Commission's "Integrated Guidelines for Growth and Jobs (2005-2008)," comprising sixteen Guidelines with only Guideline 18 mentioning gender in its title. See Commission of the European Communities, Integrated Guidelines for Growth and Jobs (2005-2008), COM (2005) 141 Final, at 28 (Apr. 2005). The counter-argument is that gender figured more prominently in the other Guidelines as a result of mainstreaming.

90. See generally Kahn Report, E.U. BuLL., no. 6 (1994). 
classes that could be protected by Community law competence. Article 13 EC also, and significantly, provided a legal base for secondary implementing legislation. To date only two Directives have been adopted with the Commission recently announcing plans for a Directive on disability discrimination. ${ }^{91}$

One Directive, Council Directive 2000/78/EC on Equal Treatment, is a broad general measure which has not been fully implemented in all of the Member States. ${ }^{92}$ The Commission sent reasoned opinions to eleven Member States on January 31, 2008 asking them to implement fully EU rules prohibiting discrimination in employment and occupation on the grounds of religion and belief, age, disability, and sexual orientation. Council Directive $2000 / 43$ on racial and ethnic discrimination ${ }^{93}$ was introduced rapidly after the Member States brushed aside their disagreements on whether and how to legislate in this area, reacting quickly to the election of Jorg Haider's Freedom Party in Austria. The Directive forbids four kinds of discrimination: direct, indirect, harassment, and instruction to discriminate. ${ }^{94} \mathrm{~A}$ race equal opportunities mainstreaming policy was introduced by Decision 2000/75 establishing an Action Programme to complement the Directive. ${ }^{95}$ A special program was adopted addressing the issues faced by the Roma who constitute one of the largest minority groups in the EU at the 2004 enlargement. ${ }^{96}$

\section{THE TROUBLE CASES}

Under the original antidiscrimination provisions relating to sex discrimination, the range of issues litigated was narrow, with a core of northern and central European Member States tending to send cases to the Court using Article 234 EC. ${ }^{97}$ In contrast the

91. See Press Release, European Parliament, MEPs Call for Comprehensive Community Legislation to Ban Discrimination (May 2008), available at http://www. europarl.europa.eu/news/expert/infopress_page/014-29032-140-05-21-902-20080516I PR29016-19-05-2008-2008-false/default_en.htm.

92. See generally Council Directive No. 2000/78/EC, O.J. L 303/16 (2000).

93. See generally Council Directive No. 2000/43/EC, O.J. L 180/22 (2000).

94. See id. art. 2.

95. See Council Decision No. 2000/750/EC, art. 1, O.J. L 303/23 (2000).

96. See generally Directorate-General for Employment and Social Affairs, Commission Green Paper on Equality and Non-Discrimination in an Enlarged European Union, (May 2004), available at http://ec.europa.eu/employment_social/publications/2004/ke6004078_ en.pdf.

97. These were Germany, the United Kingdom, the Netherlands, and Denmark. 
Commission pursued very few infringement actions against the Member States. By far the greatest interest in determining the scope of the antidiscrimination protection were cases involving the concept of indirect discrimination, often linked to the lack of protection afforded to part-time work, which was carried out predominantly by female workers. ${ }^{98}$ The concept was novel for the Member States, with the exception of the United Kingdom and the Netherlands but through the case law became an accepted norm in Community antidiscrimination measures. Other new ideas created by "trouble cases" emerged especially where national constitutional guarantees of equality were threatened, for example, the idea of positive action. Positive action was mentioned in Article 2(4) of the 1976 Equal Treatment Directive but was seen as derogation from the fundamental concept of equality of treatment. ${ }^{99}$ Thus, it should be interpreted restrictively and according to the principle of proportionality. In the first ruling on positive action, the German scheme of positive action for the public sector that created an automatic preference for one gender where that gender was underrepresented in the sector was held to be unlawful. The ruling created much controversy, which was not dampened by a Commission communication $^{100}$ explaining that the ruling affected only certain kinds of positive action schemes that were applied automatically when there was underrepresentation of one gender.

As a result of the case law, which proved to be controversial at the national level, the Member States included a permissive concept of positive action in the new wording of Article $119 \mathrm{EC}$, reformulated as Article 141(4) EC by the Treaty of Amsterdam 1997. In the recast equal opportunities Directive, Directive 2006/54/EC, Article 3 explicitly refers to positive action "within the meaning of Article 141(4) of the Treaty with a view to ensur-

98. See, e.g., Jenkins v. Kingsgate (Clothing Productions) Ltd., Case 96/80, [1981] E.C.R. 911, II 1-3; Kaufhaus v. Karin Weber von Hartz, Case 170/84, [1986] E.C.R. 1607 , I 31 .

99. See Council Directive No. 76/207, art. 2(4), O.J. L 39/40 (1976).

100. See generally Commission of the European Communities, Communication on the Interpretation of the Judgment of the Court of Justice on 17 October 1995 in Case C-450/93, Kalanke v. Freie Hansestadt Bremen, COM (96) 88 Final (Mar. 1996). In Marschall v. Land Nordrhein-Westfalen, Case C-409/95, [1977] E.C.R. I-6363, the Court accepted a different form of positive action, finding that if there were reasons specific to the male candidate to tip the balance in his favor on recruitment, these reasons could take precedence over the positive action provisions. 
ing full equality in practice between men and women in working life."101 This suggests that positive action is now seen as a constitutional principle and not as derogation from the equal treatment provisions of Community law. ${ }^{102}$ In cases decided after the Treaty of Amsterdam 1997 came into force the Court has taken different approaches. It allowed a positive action scheme using a quota system to be effective in Badeck $v$. Hessischer Ministerpräsident, ${ }^{103}$ but not a scheme that allowed a woman to be appointed over a more highly qualified male candidate for the post where women were underrepresented. ${ }^{104}$ In Lommers $v$. Minister van Landbouw, the Court allowed a childcare scheme to favor female staff, over male employees. ${ }^{105}$

Not surprisingly inequality of treatment linked to pregnancy and maternity issues also began to emerge as a greater number of European women attempted to combine paid work with motherhood. The Court created a link between pregnancy discrimination and direct gender discrimination in a groundbreaking judgment in Dekker v. Stichting Vormingscentrum voor Jong Volwassenen. ${ }^{106}$ The Court held that by refusing to employ a

101. See Council Directive No. 2006/54, art. 3, O.J. L 204/23 (2006).

102. See generally Burrows \& Robinson, supra note 77.

103. See Badeck v. Hessischer Ministerpräsident, Case C-158/97, [2000] E.C.R. I1875 , I 4.

104. See Abrahamsson v. Fogelqvist, Case C-407/98, [2000] E.C.R. I-5539, I 2.

105. See Lommers v. Minister van Landbouw, Case C-476/99, [2002] E.C.R. I-2891, I 50.

106. See, e.g., Dekker v. Stichting Vormingscentrum voor Jong Volwassenen, Case C-177/88, [1990] E.C.R. I-03941; Mahlburg v. Land Mecklenberg-Vorpommern, Case 207/98, [2000] E.C.R. I-549. The Court extended Dekker to a situation where the employer refused to appoint a pregnant woman on statutory grounds. $C f$. Hertz v. Aldi, Case C-179/88, [1990] E.C.R. I-03979, I 19. The Court did not extend the Dekker principle beyond the period of pregnancy and maternity leave. If an illness associated with the pregnancy continued after the period of maternity leave, the illness was to be treated as an "ordinary" illness. The woman should compare her situation with that of a man who was absent from work due to illness. However, this comparison is difficult to apply. First, courts have split on the issue of whether time off from work should include a period of illness during maternity absence. Compare Larsson v. Fotex Supermarket, Case C-400/95, [1977] E.C.R. I-2757, with Brown v. Rentokil Ltd., Case C-394/96, [1998] E.C.R. I-4185. Second, courts did not afford the Dekker protection where a woman is absent from work before the start of her maternity leave as a result of routine medical complaints but not related to the actual pathological condition of pregnancy or an increased risk to the unborn child. See Pedersen v. Kvickly Skive, Case C-66/96, [1998] E.C.R. 1-7327, I 5. More recent rulings have held that an employer may not take steps to dismiss a woman on the grounds related to the birth of a child for the duration of her maternity leave. See Paquay v. Société d'architectes Hoet Minne SPRL, Case C 460/06, [2007] E.C.R. I-8511, II 2. 
pregnant woman the employer was committing an act of per se direct discrimination. There was no necessity to show that she had been treated less favorably than a man who was "similarly situated" (usually the parallel for comparison was a man absent from work because of sickness). ${ }^{107}$ In Webb v. EMO Cargo the Court extended the Dekker principles to the dismissal of a pregnant woman. ${ }^{108}$ In Busch $v$. Klinikum Neustadt the Court held that an employer was committing direct discrimination by not allowing a woman to return to work before the end of her parental leave on the ground that she was pregnant for a second time. ${ }^{109}$ This case law that resulted in a broad platform of rights, paved the way for a Community-wide minimum set of employment-related protective rights for women who are pregnant and have recently given birth ${ }^{110}$ and a Parental Leave Directive. ${ }^{11}$ However these rights were not included in the modernization process that culminated in Directive 2006/54/EC.

The recognition of a set of pregnancy and maternity rights has in turn led the Court to combine ideas of equal treatment with employment protection based upon the non-discrimination principle in the recent ruling in Mayr $v$. Bäckerei und Konditorei Fläckner $O H G .^{112}$ Here a woman who was undergoing in vitro fertilization was dismissed while on a medically certified sick leave. At the date of her dismissal, ova taken from the woman had been fertilized with her partner's sperm cells but the fertilized ova were not transferred into the woman's uterus until three days after the notice of dismissal. The Court ruled that the woman did not enjoy protection from dismissal under Article

107. See Dekker, [1990] E.C.R. I-03941, I 12.

108. See Webb v. EMO Air Cargo (UK) Ltd., Case 32/93, [1994] E.C.R. I-3567, I 21; see also Hertz, [1990] E.C.R. I-03979, I 13; Brown, [1998] E.C.R. I-4185, II 16, 25-26.

109. See generally Busch v. Klinikum Neustadt, Case C-320/01, [2003] E.C.R. I-2041.

110. See generally Council Directive No. 92/85, O.J. L 348/1 (1992). These would be known as a "floor of rights" in the United Kingdom. The idea is that employers guarantee a basic set of rights to all employees. Individual employers could also provide additional rights through occupational schemes. A weakness of the approach is that the "floor of rights" is not universal. The general scheme had qualifying thresholds usually based on the number of hours employees worked each week. This was a source of conflict in the negotiations over the Pregnant Workers' Directive. The Directive provided a low ceiling to rights and a bare minimum in the absence of more generous occupational schemes.

111. See Council Directive No. 96/34, art. 2, O.J. L 145/4 (1996).

112. See generally Mayr v. Båckerei und Konditorei Fläckner OHG, Case C-506/06, [2008] E.C.R. 646. 
10(1) of Council Directive 92/85/EEC but that Articles 2(1) and 5 (1) of Council Directive 76/207/EEC would provide protection against dismissal of a female worker who was at an advanced stage of in vitro fertilization when it is shown that the dismissal is based on the fact that the woman has undergone fertilization treatment. ${ }^{113}$

The European Ombudsman has applied the Court's case law on pregnancy discrimination to a staff dispute concerning the European Parliament's refusal to change the date of the access competition for a woman who was due to give birth at the time of the competition. ${ }^{114}$ The Ombudsman recognized the fundamental rights nature of the equal treatment principle, combined with other fundamental rights such as the respect for a private and family life. ${ }^{115}$

Similarly, the basic constitutional provision of equal pay for work of equal value, Article $141 \mathrm{EG}$, has been used to challenge inequalities and unfair treatment in pay issues associated with maternity pay and leave. However, the Court appears to have created a special regime for maternity pay by holding that a woman on maternity leave was not entitled to equal pay with other workers but was entitled to an adequate amount of maternity pay. ${ }^{116}$ Soft law initiatives have created a new discourse on reconciling work and family life, finding more concrete expression in the OMC processes of the Lisbon Strategy.

In relation to other controversial areas the Court has displayed a mixed response. In $P v . S,{ }^{117}$ for example, the Court was willing to apply the general principle of non-discrimination to a gender reassignment, proclaiming the fundamental rights

113. See id. III 50-52.

114. See generally European Ombudsman Draft Recommendation, Complaint No. 3278/2004/ELB (Aug. 6, 2006), available at http://ombudsman.europa.eu/recommen/en/043278.htm.

115. See, e.g., X v. Commission, Case C-404/92 P, [1994] E.C.R. I-4737; Carpenter v. Sec'y of State for the Home Dep't, Case C-60/00, [2002] E.C.R. 6279.

116. See Gillespie v. Northern Health Services Bd. \& Social Services Bd., Case C342/93, [1996] E.C.R. I-475, I 20; see also Boyle v. Equal Opportunities Comm., Case C411/96, [1998] E.C.R. I-6401; Lewen v. Denda, Case C-333/97, [1999] E.C.R. I-7243, I 15 (holding that employers can refuse bonuses to a pregnant woman if the woman was on maternity leave). But see CNAVTS v. Thibault, Case C-136/95, [1998] E.C.R. I-2011, II $29,32-33$ (stating that employers can not automatically deny promotion to a woman just because of her maternity leave). This protection is now found in Article 15 in the revised Council Directive No. 2006/54/EC, O.J. L 204/23.

117. Pu.S Case 13/94, [1996] E.C.R. I-2143. 
nature of the principle. But, in Grant $v$. South-West Trains, the Court was restrained, holding that the principle of non-discrimination could not be applied to same-sex partnerships in the absence of national or Community legislation. ${ }^{18}$ The Court was concerned not to invade the sphere of national competence to legislate on family law and personal status. The inclusion of sexual orientation as a suspect class of antidiscrimination protection in Article 13 EC paved the way for the Court to rule that the refusal to grant a survivor's pension to a same-sex surviving spouse from a registered same-sex partnership is direct discrimination. ${ }^{119}$ However, the Court was eager to stress that its use of the antidiscrimination principle was not an interference with the Member State's competence to regulate family law. ${ }^{120}$

\section{RACE DISCRIMINATION}

The many arguments ${ }^{121}$ raised for introducing a parallel form of protection against race discrimination were answered with the adoption of a specific Directive addressing race discrimination, Directive 2000/43/EC. ${ }^{122}$ The Directive prohibits discrimination on the ground of racial or ethnic origin and applies to discrimination in the labor market as well as the supply of services such as housing, healthcare, and education. ${ }^{123}$ The Directive was to be transposed into national laws by 2003; however, it was not until 2006 that all of the Member States had introduced the Directive in one form or another. ${ }^{124}$ The Commission found many instances where the national laws did not measure up to the obligations contained in the Directive and has initiated infringement proceedings, resulting in positive judgments from

118. See Grant v. South-West Trains Ltd., Case C-249/96, [1998] E.C.R. I-621, I 50; see also D \& Sweden v. Council, Joined Cases 122/99 P \& 125/99 P, [2001] E.C.R. I4319 .

119. See Maruko v. Versorgungsanstalt der deutschen Bühnen, Case C-267/06, (ECJ Apr. 1, 2008) (not yet reported). "The case is . . part of the long process of accepting homosexuality, which is a vital step towards achieving equality and respect for all human beings." Opinion of Advocate General Ruiz-Jarabo Colomer, Case C-267/06, II 2 (ECJ Apr. 1, 2008).

120. See id. I 59.

121. See Erika Szyszczak, Race Discrimination: The Limits of Market Equality?, in DisCrimination: The Limits of Law 127, 127-29 (Bob Hepple \& Erika M. Szyszczak eds., 1992).

122. See Council Directive No. 2000/43/EC, art. 1, O.J. L 180 (2000).

123. See id. art. 1-3, O.J. L 180, at $4-5$ (2000).

124. See id. art. 16, O.J. L 180, at 9 (2000). 
the Court. ${ }^{125}$ It would seem that the initial enthusiasm for the Directive was lost in the post 9/11 world, where a new set of issues emerged on the political agenda. The range of infringement allegations reveals why so few cases have emerged in the national courts given the imprecise and inconsistent implementation of the Directive into national legal systems without a culture for legislating in the area. The Court is consistent in stating that Community law should be applied through national procedural rules ${ }^{126}$ and that there is no specific duty upon national courts to create new causes of action in the absence of specific national rules. This position creates difficulties where there are insufficient national structures in place to trigger test case litigation. The default protection provided by the ability to sue the State under the Francovich $v$. Italy ${ }^{127}$ principles is equally difficult to trigger, with few Francovich actions emerging generally, alongside the difficulty of finding the right litigant to show the harm caused by the failure to implement the Community Directives correctly. To date, only nine cases based upon the new Directives have been sent to the Court using Article $234 \mathrm{EC}$, with only one relating to race discrimination. ${ }^{128}$ This is surprising from an academic perspective since there is a long history of demanding race discrimination protection through law in Europe and there are many issues and questions that need answering through a

125. A new set of infringement proceedings were initiated in 2008. These were against: the Czech Republic, Estonia, Ireland, Greece, France, Italy, Hungary, Malta, the Netherlands, Finland, and Sweden. The national legislation is allegedly limited in terms of the people and areas it covers, as compared to the Directive (for example, lack of protection for civil servants or in access to self-employment); the definitions of discrimination which diverge from the Directive (in particular, in terms of indirect discrimination, harassment and instructions to discriminate); the lack of proper implementation of the obligation for employers to provide reasonable accommodation for disabled workers; inconsistencies in the provisions designed to help victims of discrimination (such as the shifting of the burden of proof, the rights of associations to assist individuals with their cases, and the protection against victimization). See European Parliament, Report on Progress Made in Equal Opportunities and Non-discrimination in the EU (the Transposition of Directives 2000/43/EC and 2000/78/EC), Opinion of the Committee on Civil Liberties, Justice, and Home Affairs, I 2 (Apr. 2008), available at http://www.europarl.europa.eu/sides/getDoc.do?type=REPORT\&mode=XML\& reference $=\mathrm{A} 6-2008-01598$ clanguage $=\mathrm{EN}$.

126. See generally Unibet (London) Ltd v. Justitiekanslern, Case C-432/05, [2007] E.C.R. I-2271.

127. See Francovich v. Italy, Joined Cases C-6/90 \& C-9/90, [1991] E.C.R. I-5537, II $33-40$.

128. See generally Centrum voor gelijkheid van kansen en voor racismebestrijding v. Firma Feryn NV, Case C-54/07, (ECJ July 10, 2008) (not yet reported). 
dialogue between national courts and the ECJ. A burning question is whether the wealth of principles and ideas that have been settled through the gender discrimination provisions should be read across into the new antidiscrimination classes of protection. From the little litigation that has emerged, a hierarchy appears to be in the mind of the Court where age ${ }^{129}$ and disability ${ }^{130}$ discrimination does not appear not to be afforded to the same level of protection as gender discrimination.

\section{A NEW APPROACH: REVISITING ANTIDISCRIMINATION AS A GENERAL PRINCIPLE OF COMMUNITY LAW}

The Court appeared to enhance the role the general principle of equality may play in a in a case involving alleged age discrimination against a person employed upon a fixed term contract. $^{131}$ The case was a private (or horizontal) dispute between an employer and employee and concerned an allegation of a breach of the fixed term work Directive and the general discrimination Directive, 2000/78/EC. ${ }^{132}$ The discrimination alleged was on the grounds of age, contrary to Directive 2000/78/EC but the transitional period for the Directive had not expired at the time of the dispute. ${ }^{133}$ Looking first at the fixed term work Directive, the German implementation of Framework Agree-

129. See Palacios de la Villa v. Cortefiel Servicios SA, Case C-411/05, [2007] E.C.R. I-8531, II 31, 33; see also Erica Howard, The Case for a Considered Hierarchy of Discrimination Crounds in EU Law, 13 MAAsTRICHT J. EuR. \& CoMP. LAW 445 (2006); see generally L. Waddington \& Mark Bell, More Equal Than Others Than Others: Distinguishing European Union Equality Directives, 38 Common Mкт. L. Rev. 587 (2001).

130. See Navas v. Eurest Colectividades SA, Case C-13/05, [2006] E.C.R. I-6467, II $18-22$.

131. See generally Mangold v. Helm, Case C.144/04, [2005] E.C.R. I-9981.

132. See generally Bartsch v. Bosch und Siemens Hausgeräte (BSH) Altersfürsorge $\mathrm{GmbH}$, Case C-427/06 (ECJ Sept. 23, 2008) (not yet reported). The Advocate General in Bartsch $v$. Bosch und Siemens Hausgeräte (BSH) Altersfürsorge $G m b H$ points out that the dispute in Mangold was essentially attacking the underlying German law, which had implemented Community Law Directive. However, the Court also comments,

[i]n Mangold the Court applied the general principle of equal treatment (including equal treatment irrespective of age) to a private dispute between individuals, albeit one governed by national rules of public law put in place to implement a Community law obligation (Directive 1999/70). It therefore seems that I should be slow to exclude the possibility that a general principle Id. I 85.

of Community law may, in appropriate circumstances, be applied horizontally. 2006).

133. See id. If 6 (stating that the directive was to be implemented by December 2 , 
ment 1999 on fixed term work gave no protection for workers aged fifty-two or over. ${ }^{134}$ The Court found that the German law implementing the Directive could give rise to age discrimination and although the German government had a legitimate aim in mind when it implemented the Directive (the aim of achieving flexibility in labor markets by creating job opportunities for younger workers), the German method of implementing the public interest aim in this case did not satisfy the principle of proportionality. ${ }^{135}$ The Court then, at Paragraphs 75 and 76, recognized that the principle of non-discrimination on grounds of age was a general principle of Community law:

The principle of non-discrimination on grounds of age must thus be regarded as a general principle of Community law. Where national rules fall within the scope of Community law ... and reference is made to the Court for a preliminary ruling, the Court must provide all the criteria of interpretation needed by the national court to determine whether those rules are compatible with such a principle (Case C-442/00 Rodríguez Caballero [2002] ECR I-11915, paragraphs 30 to 32). ${ }^{136}$

Consequently, observance of the general principle of equal treatment, in particular in respect of age, cannot as such be conditional upon the expiry of the period allowed the Member States for the transposition of a directive intended to lay down a general framework for combating discrimination on the grounds of age, in particular so far as the organization of appropriate legal remedies, the burden of proof, protection against victimization, social dialogue, affirmative action, and other specific measures to implement such a directive are concerned. ${ }^{137}$

The Court concluded that, irrespective of the deadline for implementing the Directive 2000/78:

[I] $t$ is the responsibility of the national court to guarantee the full effectiveness of the general principle of non-discrimination in respect of age, setting aside any provision of national law which may conflict with Community law. ${ }^{138}$

134. See Mangold, [2005] E.C.R. I-9981, II 18-19.

135. See id. 11 58-60.

136. Id. I 75.

137. Id. II 76 .

138. Id. ๆ 78. 
The Court thus places the duty upon the national court to interpret national law to ensure compatibility with Community law, guaranteeing Community law rights for all individuals. The thrust of the judgment is one of effectiveness. The Mangold $v$. Helm approach has been criticized by Advocates General ${ }^{139}$ and by academic commentators. ${ }^{140}$ In Lindorfer $v$. Council, ${ }^{141}$ a staff case, Advocate General Sharpston examined how Directive $2000 / 78$ fits into the scheme of Community law on non-discrimination. The Advocate General took the view that a better reading of Mangold is not that Community law contained a specific pre-existing principle of non-discrimination on grounds of age but that discrimination on such grounds had always been precluded by the general principle of equality. ${ }^{142}$ Thus, Directive 2000/78 introduced a specific, detailed framework for dealing with age (and indeed other suspect classes) of discrimination.

139. See Bartsch v. Bosch und Siemens Hausgeräte (BSH) Altersfürsorge GmbH, Case C-427/06, slip op., III 31-33 (ECJ Sept. 23, 2008) (not yet reported); see also Palacios de la Villa v. Cortefiel Servicios SA, Case C-411/05, [2007] E.C.R. I-8531 (arguing that the international instruments and constitutional traditions referred to by the ECJ in Mangold $v$. Helm embrace the general principle of equal treatment, but that the Court appears to jump too far in its reasoning to infer that from the existence of these standards there is a specific prohibition against age discrimination); $c$. Navas v. Eurest Colectividades SA, Case C-13/05, [2006] E.C.R. I-6467 (concerned with the potentially far-reaching economic and financial consequences of claims to equal treatment based on Article 13 EC). In each case, the Court did not comment on the criticisms raised against Mangold.

140. See generally Alan Dashwood, From Van Duyn to Mangold via Marshall: Reducing Direct Effect to Absurdity?, 9 Cambridge Y.B. Eur. L. 81 (2006); see also Joel Cavallini, De la Suppression des Resirictions à la Conclusion d'un Contrat à Durée Déterminée Lorsque le Salarié est un Senior, La Semaine Juridieue Sociale 25 (2005); Olivier Dubos, La Cour de Justice, le Renvoi Préjudiciel, l'Invocabilité des Directives: de l'Apostasie à l'Hérésie?, LA Semaine Juridique Sociale, 1295 (2006); O. LeClerc, Le Contrat de Travail des Seniors à l'Épreuve du Droit Communautaire, Recueil Dalloz 557 (2006); M. Nicolella, Une Application Anticipée des Directives non Transposées?, Gazette du Palais, 22 (2006); Edouard Dubout, On Mangold, Revue des Affaires Européennes 723 (2005); A. Masson \& C. Micheau, The Werner Mangold Case: An Example of Legal Militancy, Eur. PuB. L. 587 (2007); Editorial Comments, Common Mкт. L. Rev. 1 (2006); cf. Malcolm Ross, Effectiveness in the European legal Order(s): Beyond Supremacy to Constituional Proportionality, 31 Eur. L. Rev. 476 (2006) (arguing that while Directives do not confer rights on individuals directly they do impose obligations upon the Member States that create secondary consequences for non-State parties. Thus cases such as Mangold seek to promote and maximize the principle of the effectiveness of Community law wherever possible while not explicitly creating horizontal direct effect for Directives).

141. Lindorfer v. Council, Case C-427/06 P [2007] E.C.R. I-6767 (cited in Centrum voor gelijkheid van kansen en voor racismebestrijding v. Firma Feryn NV, Case Cr54/07, slip op., II 58 (ECJ July 10, 2008) (not yet reported)).

142. See Bartsch, slip op., II 34 . 
The Court did not address this point its judgment. Advocate General Ruiz-Jarabo Colomer has taken the view in Maruko v. Versorgungsanstalt der deutschen Bühnen that the "essential character" of the right to non-discrimination on the ground of sexual orientation is of a different order to that which the Court attributed to the principle of non-discrimination based on age in Mangold. ${ }^{143}$ In Coleman v. Attridge Law, Advocate General Maduro describes the interpretation of Mangold as a "practical aspect of the principle of equality." ${ }^{44}$ The Court has the opportunity to revisit the issue in a pending case, Bartsch v. Bosch und Siemens Hausgeräte (BSH) Altersfürsorge $G m b H .{ }^{145}$ Advocate General Sharpston has argued that the substantive issue of the dispute does not fall within Community law competence.

\section{TIME TO MOVE ON . . BUT WHERE TO?}

The success of a policy on antidiscrimination cannot be measured entirely in the amount of litigation it generates and the raw statistical evidence from Europe suggests that the antidiscrimination policy of the Community has resulted only in partial changes to the way European society organizes itself economically, politically, and socially. As in the United States, law plays an important role in generating a new discourse about how a community should value its members. The impact of the new raft of Article $13 \mathrm{EC}$ measures has yet to be seen, with the Member States dragging out the implementation of the secondary law and few references making their way to the ECJ. With only nine references sent by the national courts using Article $234 \mathrm{EC}$, the result is an uneven and disappointing development of anti-discrimination concepts with disagreement evident within the Court. Yet the litigation, which continues around the older set of anti-discrimination provisions, reveals that the Court is receptive to expanding the existing provisions to allow for greater opportunities. These opportunities are not only for antidiscrimination to be developed as a concept but also for the practical reali-

143. See generally Maruko v. Versorgungsanstalt der deutschen Bühnen, Case C267/06 (ECJ Apr. 1, 2008) (not yet reported).

144. See Opinion of Advocate General Poiares Maduro, Coleman v. Attridge Law \& Steve Law, Case C-303/06, slip op. I 8 (ECJ Jan. 31, 2008) (not yet reported).

145. See Opinion of Advocate General Sharpston, Bartsch v. Bosch und Siemens Hausgeräte (BSH) Altersfürsorge GmbH, Case 427/06, slip op., II 1 (ECJ May 22, 2008) (not yet reported). 
zation of equal opportunity to continue to emerge. For example, in Lommers, the Court accepted the legality of a subsidized child-care scheme which was available mainly for female employees, recognizing that women were, in reality the principal caretakers of children, and this role created difficulties in reconciling work and family life. ${ }^{146}$ In Kiiski $v$. Tampereen Kaupunki, a woman who had given birth in 2003 was granted child-care leave from August 2004 until June 2005. ${ }^{147}$ During this leave she became pregnant again and asked for the original leave to be amended to end on December 22, 2004 so that she could generate a second set of maternity and child-care leave arrangements for herself and transfer the first set to her partner. ${ }^{148}$ This request was rejected by the employer who argued that the Finnish collective agreement and case law allowed an amendment of an original request for child-care leave only if there was a fundamental change in the conditions in which she could care for her child; a new pregnancy was not such a condition. ${ }^{149}$ The father of the child was not allowed to take childcare leave because under the collective agreement only one parent could take the leave at a given time. The Court accepted that Ms. Kiiski wanted to interrupt her leave to enable her to take maternity leave and transfer the child-care leave to the father.

This embedding of equal opportunity has taken many years to be realized through the use of soft law, hard law, and most importantly, case law. There are discernible tendencies in the language of the legislation and the case law for a move towards more substantive notions of equality, using the principle of antidiscrimination combined with positive action approaches. ${ }^{150}$ In order for other forms of antidiscrimination to achieve the same status, the Community cannot endure such a long timeframe. Equally the Community rests upon traditional and largely uncontroversial notions of direct and indirect discrimination, with a limited acknowledgement of positive action. It urI1 16.

146. See Lommers v. Minister van Landbouw, Case C-476/99, [2002] E.C.R. I-2829,

147. See Kiiski v. Tampereen Kaupunki, Case 116/06, [2007] E.C.R. I-7643, I 17.

148. See id. II 18-19.

149. See id. II 19.

150. See generally Erica Howard, The European Year of Equal Opportunities for All2007: Is the EU Moving Away From a Formal Idea of Equality, 14(2) EuR. L.J. 168 (2008) (discussing the EU's directives on fighting discrimination and promoting equality and equal treatment). 
gently needs a new generation of ideas given the complexity of modern life. There are some hints that this new generation of ideas can emerge through the traditional case law approach. For example, Advocate General Maduro in an Opinion in Cole$m^{151}$ opened the door for moving the discrimination concept forward, firstly by extending the ambit to protect a person who is associated with one of the suspect categories, in this case disability, because of her caring responsibilities, and secondly, by linking the purpose of discrimination law to realizing personal autonomy, and an empowering principle, rather than seeing discrimination in a passive sense of providing protection from the victimization which is often ingrained in discriminatory behavior. This idea is set out in paragraph 11:

[A] commitment to autonomy means that people must not be deprived of valuable options in areas of fundamental importance for their lives by reference to suspect classifications. Access to employment and professional development are of fundamental significance for every individual, not merely as a means of earning one's living but also as an important way of self-fulfillment and realisation of one's potential. The discriminator who discriminates against an individual belonging to a suspect classification unjustly deprives her of valuable options. As a consequence, that person's ability to lead an autonomous life is seriously compromised since an important aspect of her life is shaped not by her own choices but by the prejudice of someone else. By treating people belonging to these groups less well because of their characteristic, the discriminator prevents them from exercising their autonomy. At this point, it is fair and reasonable for anti-discrimination law to intervene. In essence, by valuing equality and committing ourselves to realising equality through the law, we aim at sustaining for every person the conditions for an autonomous life. ${ }^{152}$

The case concerned the mother of a child with serious disabilities. She claimed that she was discriminated against by her employer (a law firm) after she returned to work from maternity leave and subsequently during her employment when she required time off work to care for her child. ${ }^{153}$ The behavior of

151. See Opinion of Advocate General Poiares Maduro, Coleman v. Attridge Law, Case 303/06, slip op. II 10-11 (ECJ Jan. 31, 2008) (not yet reported).

152. Id. I 11 .

153. See id. I 3. 
the employer (and co-workers) was a form of harassment and may have been covered by an expansive interpretation of the protection of "family status" under the Equal Treatment Directive. Instead, the claim was brought under the British Disability Discrimination Act and Council Directive 2000/78 on equal treatment. Her argument was that the Directive was intended to prohibit discrimination not only against disabled persons but also against individuals who are victims of discrimination because they are associated with a disabled person. ${ }^{154}$ The Advocate General takes a teleological approach by looking behind the purpose of Article $13 \mathrm{EC}$ :

Article $13 \mathrm{EC}$ is an expression of the commitment of the Community legal order to the principle of equal treatment and non-discrimination. Thus, any interpretation of both that article and any directive adopted under this legal basis must be undertaken against the background of the Court's case-law on these principles. The Directive itself states in Article 1 that its purpose is 'to lay down a general framework for combating discrimination ... with a view to putting into effect in the Member States the principle of equal treatment.' The Court's case-law is clear as regards the role of equal treatment and non-discrimination in the Community legal order. Equality is not merely a political ideal and aspiration but one of the fundamental principles of Community law. As the Court held in Mangold the Directive constitutes a practical aspect of the principle of equality. In order to determine what equality requires in any given case it is useful to recall the values underlying equality. These are human dignity and personal autonomy. ${ }^{155}$

While the language of this Opinion moves Community law thinking further than has hitherto been seen in the judgments of the Court, it also echoes the much earlier sentiments of the ILO Conventions, discussed above, of examining the purpose of the law relating to antidiscrimination, relating it to the dignity of the individual. This approach is also seen in a subsequent Opinion by the same Advocate General in Centrum voor gelijkheid van kansen en voor racismebestrijding $v$. NV Firma Feryn, ${ }^{156}$ the first refer-

154. See id. I 4.

155. See id. I 8 (citations omitted).

156. See Opinion of Advocate General Poiares Maduro, Centrum voor Gelijkheid van Kansen en voor Racismebestrijding v. Firma Feryn NV, Case C-54/07, slip op., III 9 , 14, 17 (ECJ Mar. 12, 2008) (not yet reported). 
ence to the Court using the concept of direct discrimination in Council Directive 2000/43/EC. ${ }^{157}$ Here an employer had used directly discriminatory selection criteria stating that (allegedly) in response to his customers' wishes he would only employ indigenous fitters from Belgium to install his products in customers' homes. ${ }^{158}$ The case appears quite shocking for an English (or indeed an American) reader, since it recalls the overt discrimination seen in the notices of "no blacks wanted" in employment, housing and the services sector which drew the response of the initial antidiscrimination legislation of the 1960s and the early debates as to whether the antidiscrimination principle could extend to the "private" sphere of services, housing and personal employment in the home. ${ }^{159}$

The case raises many new issues at the European level on the standard of proof. The employer had appeared on television and placed earlier notices explaining his employment hiring policy and had issued a joint press release with the national body for combating discrimination. The case also raises issues of proof of indirect discrimination. Can the fact that the employer does not employ anyone from an ethnic minority give rise to a presumption of indirect discrimination? Is one factual situation enough to raise a presumption of discrimination? Conversely, can the employer escape liability by stating that one employee does have an ethnic background and making a declaration reversing the earlier declaration to state that employees from an ethnic minority background are indeed welcome to apply for jobs? Again, Advocate General Maduro looks to the purpose and reasons behind Article 13 EC. He introduces another novel idea into European law, the idea of "speech acts." 160 This would cover the situation where no physical or discernible act of discrimination has taken place against a specific individual but where the act of saying something amounts to the carrying out of an act.

These two cases throw down the gauntlet to move antidiscrimination law into a new era of individual and collective rights. The cases since 2000, when the implementing Directives of Article 13 EC were introduced, have been limited to a number of

157. See Council Directive No. 2000/43/EC, arts. 2-3, O.J. L 180/22, at 24 (2000).

158. See Centrum, slip op., II 16.

159. See generally Centrum, slip op.

160. See Opinion of Advocate General Maduro, Centrum, slip op., I 16. 
formal infringement actions and a handful of ad hoc Article 234 EC references. More coordinated strategic litigation needs to take place in order to get to the heart of a number of key concepts in the new areas of suspect classes protected by the antidiscrimination concept. These issues should discuss whether the same principles can be read across all of the suspect classes: when does the reversal of the burden of proof apply, is segregation a form of direct and/or indirect discrimination, what is the role of positive action, what are effective remedies, what are appropriate remedies for victimization complaints?

The increase in social law and social policy in the Community after 1997 has created a wide platform of hard and soft law policy fora. Paradoxically this can open up new opportunities but also create competition for the use of the fora by different policy actors. This is seen for example in October 2007 when the Commission indicated in its Legislative and Work Programme for 2008 that it was necessary, in the light of Article 13 $\mathrm{EC}$, to adopt a new antidiscrimination Directive providing protection for all the suspect classes covered by Article 13 EC. ${ }^{161}$ Yet, disappointingly, in the subsequent proposal the Commission only focused upon disability discrimination, an area where representation in the "civil society" of Community policy-making is articulate, professionally prepared, and highly organized. ${ }^{162}$

Gazing at a crystal ball is always a risk. My guess is that what the next fifty years will hold for antidiscrimination law in Europe will depend upon how far existing law and policy is able to sustain the changes in society, especially the role of women in the public workplace and men in the private sphere of family life, against growing, and what could be countervailing factors of multiculturalism in Europe and the impact this has on the organization of private and public life. Race and ethnic discrimination, together with political rights on freedom of speech and belief, will dominate the public agenda on how antidiscrimination is handled in Europe. This political, and legal, debate will take place against the countervailing, and often repressive, growth of racism and xenophobia in the uncertain economic cli-

161. See European Commission, The Commission's Work Programme for 2008 25, available at http://ec.europa.eu/atwork/programmes/index_en.htm.

162. See European Commission, Executive RePort 2008 at 1, available at http:// ec.europa.eu/atwork/programmes/index_en.htm. 
mate and the political measures taken in the "War on Terror." These will be the main challenges as to how far European society is able to uphold the constitutional values proclaimed judicially by the European Court and politically by the TEU and TFEU created by the Treaty of Lisbon 2007 . To end on a note of optimism, read the Opinion of Advocate General Maduro in Kadi. ${ }^{163}$ A resident of Saudi Arabia, Kadi, was designated by the UN Security Council Sanctions Committee as a person suspected of supporting terrorism. Under United Nations Resolutions, the Member States of the United Nations are required to freeze the funds and financial resources of such suspects. The Community gave effect to these obligations in Council Regulation (EC No. 1881/2002) that included, in an annex, a renewable list of persons deemed to fall within the United Nations Sanctions Committee list of people suspected of supporting terrorism. ${ }^{164}$ Kadi brought an action before the Court of First Instance for the annulment of EC Regulation No 1881/2002, claiming that the Council lacked competence to adopt it and that the Regulation breached several personal fundamental rights, for example, the right to property and the right to a fair hearing. ${ }^{165}$ The Court of First Instance rejected all of Kadi's pleas and the case is now on appeal to the ECJ. ${ }^{166}$ Advocate General Maduro, in finding that the Regulation is a reviewable act, also found that Kadi's fundamental rights had been infringed:

Both the right to be heard and the right to effective judicial review constitute fundamental rights that form part of the general principles of Community law. According to settled case-law, 'observance of the right to be heard is, in all proceedings initiated against a person which are liable to culminate in a measure adversely affecting that person, a fundamental principle of Community law which must be guaranteed even in the absence of any rules governing the proceedings in question. ... That principle requires that the addressees of decisions which significantly affect their interests should be placed in a position in which they may effectively make known their views.' As to the right to effective judicial review, the Court has held: 'The European Community is ...

163. See generally Opinion of Advocate General Poiares Maduro, Kadi v. Council, Case C-402/05 P (ECJ Jan. 16, 2008) (not yet reported).

164. See Council Directive No. 881/2002, Annex I, O.J. L 139/9, at 12 (2002).

165. See Opinion of Advocate General Poiares Maduro, Kadi, slip op., II 8-9.

166. See id. I 9. 
a community based on the rule of law in which its institutions are subject to judicial review of the compatibility of their acts with the Treaty and with the general principles of law which include fundamental rights. ... Individuals are therefore entitled to effective judicial protection of the rights they derive from the Community legal order, and the right to such protection is one of the general principles of law stemming from the constitutional traditions common to the Member States. ${ }^{167}$ 